\title{
Incorporation of nitrogen from amino acids and urea by benthic microbes: role of bacteria versus algae and coupled incorporation of carbon
}

\author{
Bart Veuger*, Jack J. Middelburg \\ Netherlands Institute of Ecology (NIOO-KNAW), Centre for Estuarine and Marine Ecology, PO Box 140, 4400 AC Yerseke,
} The Netherlands

\begin{abstract}
We investigated the incorporation of nitrogen from amino acids and urea by the microbial community in intertidal surface sediment, focusing on the relative contributions of bacteria versus algae to total microbial nitrogen incorporation and the (un)coupled incorporation of carbon from these organic substrates. Dual-labeled $\left({ }^{15} \mathrm{~N}\right.$ and $\left.{ }^{13} \mathrm{C}\right)$ urea and an amino acid mixture were added to surface sediment from 2 intertidal mudflats in the Scheldt Estuary (The Netherlands), and ${ }^{15} \mathrm{~N}$ and ${ }^{13} \mathrm{C}$ were subsequently traced into bulk sediment, total hydrolysable amino acids (THAAs) and the bacterial biomarker D-alanine (D-Ala) over a $24 \mathrm{~h}$ incubation period. All added ${ }^{15} \mathrm{~N}$ from urea and the amino acids was incorporated into microbial biomass within $24 \mathrm{~h}$, with relatively rapid incorporation of ${ }^{15} \mathrm{~N}$ from the amino acids. The bacterial contribution to total microbial ${ }^{15} \mathrm{~N}$ incorporation (derived from ${ }^{15} \mathrm{~N}$ incorporation into D-Ala) was large during the first 1 to $2 \mathrm{~h}$ of incubation, but small to negligible after $24 \mathrm{~h}$ for both substrates, indicating that total ${ }^{15} \mathrm{~N}$ incorporation was dominated by benthic microalgae (diatoms) that also dominated total microbial biomass in the sediment. Comparison of ${ }^{15} \mathrm{~N}$ versus ${ }^{13} \mathrm{C}$ incorporation into total microbial biomass (THAAs) after $24 \mathrm{~h}$ showed strong preferential incorporation of urea-N over urea-C. Incorporation of nitrogen and carbon from the amino acids was partially uncoupled, indicating that a large fraction $(\geq 50 \%)$ of amino acid-N was taken up as $\mathrm{NH}_{4}{ }^{+}$ resulting from extracellular amino acid oxidation.
\end{abstract}

KEY WORDS: Nitrogen uptake $\cdot$ Urea $\cdot$ Amino acids $\cdot$ Bacteria $\cdot$ Benthic microalgae $\cdot$ Sediment Hydrolysable amino acids $\cdot \mathrm{D}$-alanine

\section{INTRODUCTION}

Microbial uptake of dissolved nitrogen is an important process in aquatic systems because nitrogen is an essential element for microbial growth and can be a limiting factor for aquatic microbial production. Although traditional research typically focused on uptake of dissolved inorganic nitrogen (DIN), it is now clear that dissolved organic nitrogen (DON) can also be an important nitrogen source for aquatic microbial communities. Two important forms of DON are urea and amino acids, of which the latter can be present as individual amino acids or in a combined form (proteins, peptides). Although urea and amino acids generally make up no more than $\sim 20 \%$ of the total aquatic DON pool, these labile compounds are relatively important nitrogen sources for the microbial community and can account for a large fraction of total microbial nitrogen uptake in coastal waters (Bronk 2002, Veuger et al. 2004). Microbial nitrogen uptake has been studied extensively, especially by ${ }^{15} \mathrm{~N}$-labeling. However, some of its aspects are still unclear.

One aspect that has remained largely unresolved is the relative importance of algae versus bacteria, the 2 main groups involved in microbial uptake of dissolved nitrogen. Methods used to discriminate ${ }^{15} \mathrm{~N}$ uptake by specific microbial groups include size fractionation (physical separation of relatively small bacteria from relatively large algae by filtration or flow cytometry) and the use of inhibitors to eliminate activity of a spe- 
cific group (e.g. Wheeler \& Kirchman 1986, Lipschultz 1995, Middelburg \& Nieuwenhuize 2000). However, application of these methods in turbid waters and sediments is highly problematic, meaning that specific assessment of ${ }^{15} \mathrm{~N}$ uptake by bacteria versus algae in these systems has so far been hampered by a lack of adequate methodology. Only recently was ${ }^{15} \mathrm{~N}$-labeling combined with analysis of ${ }^{15} \mathrm{~N}$ incorporation into bacterial amino acids, which allowed specific assessment of ${ }^{15} \mathrm{~N}$ incorporation into bacterial biomass (Tobias et al. 2003, Veuger et al. 2005).

Another understudied aspect of aquatic microbial nitrogen uptake is the (un)coupling between uptake of nitrogen and carbon from organic compounds. Studies on algal cultures have shown that incorporation of urea- $\mathrm{N}$ is uncoupled from urea-C (Price \& Harrison 1988, Antia et al. 1991), while both coupled and uncoupled uptake of nitrogen and carbon has been reported for amino acids (Algeus 1948, Stephens \& North 1971, Palenik \& Morel 1990, Antia et al. 1991). For natural aquatic microbial communities, uptake of $\mathrm{N}$ and $\mathrm{C}$ from organic compounds has been studied using duallabeled urea (Mulholland et al. 2004, Fan \& Glibert 2005, Andersson et al. 2006) and amino acids (Schell 1974, Zehr et al. 1985, Mulholland et al. 2002, 2003, 2004, Andersson et al. 2006). In general, these studies found that amino acids can supply both $\mathrm{N}$ and $\mathrm{C}$ for microbial growth, while urea serves as a source of $\mathrm{N}$ only. However, exceptions have been reported and the factors controlling uptake of $\mathrm{N}$ and $\mathrm{C}$ are still largely unclear. One important controlling factor may be the composition of the microbial community responsible for uptake and incorporation of the $\mathrm{N}$ and/or $\mathrm{C}$. The recent introduction of a method for analysis of ${ }^{15} \mathrm{~N}$ and ${ }^{13} \mathrm{C}$ incorporation by bacteria (Veuger et al. 2005) may help to resolve this point.

A third aspect of aquatic microbial nitrogen uptake is that work on this subject so far primarily involved studies on nitrogen uptake by the microbial community in the water column, while microbial nitrogen uptake in sediments has remained largely unstudied. This is mainly due to methodological problems, because analysis of total ${ }^{15} \mathrm{~N}$ uptake by the total benthic microbial community was hampered by the inability to differentiate between ${ }^{15} \mathrm{~N}$ incorporated into microbial biomass and other ${ }^{15} \mathrm{~N}$ pools in the sediment (e.g. extracellular ${ }^{15} \mathrm{~N}$-labeled material bound to the sediment). However, by combining ${ }^{15} \mathrm{~N}$-labeling with analysis of ${ }^{15} \mathrm{~N}$ incorporation into total hydrolysable amino acids (THAAs, representing total proteinaceous biomass) it is now possible to specifically trace ${ }^{15} \mathrm{~N}$ incorporation into microbial biomass within sediments (Veuger et al. 2005).

In the present study, we investigated the incorporation of ${ }^{15} \mathrm{~N}$ and ${ }^{13} \mathrm{C}$ from dual-labeled urea and amino acids by algae and bacteria in intertidal surface sediment. Analysis of ${ }^{15} \mathrm{~N}$ and ${ }^{13} \mathrm{C}$ incorporation into THAAs, including the bacterial biomarker D-alanine (D-Ala), allowed us to clarify the relative contributions of bacteria versus algae to total microbial ${ }^{15} \mathrm{~N}$ incorporation and the coupling between incorporation of $\mathrm{N}$ and $\mathrm{C}$ from urea and amino acids.

\section{MATERIALS AND METHODS}

Sediment collection. Sediment was collected from 2 intertidal mudflats in the mid region (salinity 20 to 25) of the turbid, nutrient-rich and heterotrophic Scheldt Estuary (The Netherlands) (see Soetaert et al. 2006) during low tide on 1 June 2004. The first site was characterized by sediment patches covered by a diatom biofilm, and sediment was sampled from these patches. The second site (Biezelingsche Ham) was a mudflat $\sim 5 \mathrm{~km}$ from the first site. At this site, no visible diatom biofilm was present, which was likely related to the high densities of diatom-grazing fauna at this site. At both sites, $\sim 500 \mathrm{ml}$ of surface sediment (upper $\sim 10 \mathrm{~mm}$ ) was collected as well as water from nearby intertidal pools. Sediment collection at the 2 sites and subsequent transportation of the sediment to the laboratory was completed within $2 \mathrm{~h}$. Hereafter, we refer to the sediment from the first and second site as 'BMA+' and 'BMA-' respectively, which reflects the relative difference in abundance of benthic microalgae (BMA) at the 2 sites.

Labeling and incubations. In the laboratory, subsamples $(20 \mathrm{ml})$ of homogenized sediment were diluted with $20 \mathrm{ml}$ water from the nearby intertidal pools in slurry bottles $(100 \mathrm{ml}, 35 \mathrm{~mm}$ internal diameter). Incubations were started by addition of $1 \mathrm{ml}$ of $0.8 \mathrm{mM}{ }^{13} \mathrm{C}$-urea (Cambridge Isotope Laboratories, CLM-311, 99\% ${ }^{13} \mathrm{C}$ ) and $1 \mathrm{ml}$ of $0.8 \mathrm{mM}{ }^{15} \mathrm{~N}$-urea (Cambridge Isotope Laboratories, NLM-233, $\geq 98 \%$ ${ }^{15} \mathrm{~N}$ ), or $1 \mathrm{ml}$ of a ${ }^{13} \mathrm{C}$-labeled amino acid mixture (0.8 mM) (Cambridge Isotope Laboratories, CLM-1548, $\geq 98 \%{ }^{13} \mathrm{C}$ ) and $1 \mathrm{ml}$ of the same amino acid mixture but ${ }^{15} \mathrm{~N}$-labeled (Cambridge Isotope Laboratories, NLM2161,96 to $99 \%{ }^{15} \mathrm{~N}$ ). This amino acid mixture (hereafter referred to as 'AA-mix') is an algal-derived mixture containing the following amino acids (with approximate mole \% as indicated by the manufacturer): Ala (7\%), Arg (7\%), Asp (10\%), Glu (10\%), Gly $(6 \%)$, His $(2 \%)$, Ile $(4 \%)$, Leu $(10 \%)$, Lys $(14 \%)$, Met $(1 \%)$, Phe $(4 \%)$, Pro $(7 \%)$, Ser $(4 \%)$, Thr $(5 \%)$, Tyr $(4 \%)$ and Val $(5 \%)$. Added concentrations of labeled urea and dissolved free amino acids (DFAAs) were 5 to 8 times higher than ambient pore water concentrations. After addition of the labeled substrates, samples were homogenized by gentle shaking and placed outdoors (around noon) under ambient light and tempera- 
ture $\left(\sim 25^{\circ} \mathrm{C}\right)$. After shaking, the sediment quickly settled to form a homogenized layer ( $2 \mathrm{~cm}$ thick). Bottles were left open during incubation. Incubations were terminated after $0.5,1,2,4,7$ and $24 \mathrm{~h}$, of which the $24 \mathrm{~h}$ incubations included $7.5 \mathrm{~h}$ of darkness (between $10 \mathrm{~h}$ and $17.5 \mathrm{~h}$ ). An additional set of AA-mix incubations was terminated directly after addition of the labeled AA-mix, which resulted in an effective incubation period of 10 to $15 \mathrm{~min}$. Incubations were terminated by transferring the slurries to $50 \mathrm{ml}$ centrifuge tubes that were dipped in liquid nitrogen to stop microbial activity. Subsequently, thawed samples were centrifuged $(10 \mathrm{~min}$ at $600 \times g)$ and supernatants were filtered (GF-6 and $0.2 \mu \mathrm{m}$ cellulose), transferred to headspace vials $(10 \mathrm{ml})$, capped, killed with $100 \mu \mathrm{l}$ of a saturated $\mathrm{HgCl}$ solution and stored at $4{ }^{\circ} \mathrm{C}$ for ${ }^{13} \mathrm{C}$-DIC (dissolved inorganic carbon) analysis (see section 'Analyses'). Sediment pellets were frozen at $-20^{\circ} \mathrm{C}$ and freeze dried for analysis of ${ }^{15} \mathrm{~N}$ and ${ }^{13} \mathrm{C}$ in bulk sediment and (HAAs) (see section 'Analyses' for details).

Analyses. ${ }^{15} \mathrm{~N}$ and ${ }^{13} \mathrm{C}$ in the bulk sediment was measured using a Fisons CN elemental analyzer coupled on-line to a Finnigan Delta $\mathrm{S}$ isotope ratio mass spectrometer (EA-IRMS). Samples for ${ }^{13} \mathrm{C}$ analysis were acidified to remove carbonates. ${ }^{15} \mathrm{~N}$ and ${ }^{13} \mathrm{C}$ incorporation into HAAs, including the bacterial biomarker D-Ala, was analyzed as described by Veuger et al. (2005). Briefly, samples of freeze-dried sediment $(1 \mathrm{~g})$ were washed with $2 \mathrm{M} \mathrm{HCl}$ and Milli-Q water in order to remove dissolvable material (free and sediment-bound) and subsequently hydrolyzed in $6 \mathrm{M}$ $\mathrm{HCl}$ at $110^{\circ} \mathrm{C}$ for $20 \mathrm{~h}$. After purification by cation exchange chromatography, amino acids were derivatized with isopropanol (IP) and pentafluoropropionic anhydride (PFA), and samples were further purified by solvent extraction. The relative abundance of ${ }^{15} \mathrm{~N}$ and ${ }^{13} \mathrm{C}\left(\delta^{15} \mathrm{~N}\right.$ and $\left.\delta^{13} \mathrm{C}\right)$ in the derivatized $\mathrm{D}$ - and Lamino acids were analyzed by gas chromatographycombustion-isotope ratio mass spectrometry (GC-CIRMS) during separate sessions for ${ }^{15} \mathrm{~N}$ - and ${ }^{13} \mathrm{C}$-analyses. Additional information on ${ }^{13} \mathrm{C}$ analysis can be found in Veuger et al. (2006). Because of time constraints, ${ }^{13} \mathrm{C}$ analyses were only performed for samples from 4 and $24 \mathrm{~h}$ incubations. Unfortunately, only a few samples from the BMA+ slurries incubated with urea could be analyzed for ${ }^{15} \mathrm{~N}$ and ${ }^{13} \mathrm{C}$ enrichment of HAAs because part of these samples were lost during sample processing.

${ }^{13} \mathrm{C}$ analysis of pore water DIC was performed $\sim 2 \mathrm{wk}$ after the experiment. A helium headspace replaced $2 \mathrm{ml}$ of the water in the vials, and subsequently samples were acidified (to convert all DIC to $\mathrm{CO}_{2}$ ), shaken, and the headspace gas analyzed by GC-IRMS.

A selection of samples was analyzed for concentrations of phospholipid-derived fatty acids (PLFAs) by
GC-C-IRMS to obtain an estimate of bacterial biomass in the sediment slurries (see Middelburg et al. 2000). For analysis of ambient concentrations of urea and dissolved free amino acids (DFAA), pore water was extracted from unlabeled slurries by centrifugation $(10 \mathrm{~min}$ at $600 \times g)$ and the resulting supernatant was filtered through Whatman GF/F filters and stored frozen at $-20^{\circ} \mathrm{C}$. Urea concentrations were measured by a standardized colorimetric technique (Middelburg \& Nieuwenhuize 2000), and DFAA concentrations by HPLC (Fitznar et al. 1999). For analysis of photosynthetic pigment concentrations, additional sediment samples were frozen, freeze dried, stored frozen $\left(-20^{\circ} \mathrm{C}\right)$ and later analyzed by HPLC (Barranguet et al. 1997).

Data treatment. ${ }^{15} \mathrm{~N}$ and ${ }^{13} \mathrm{C}$ enrichments are expressed as excess ${ }^{15} \mathrm{~N}$ and ${ }^{13} \mathrm{C}$ per gram dry sediment, which was calculated as: excess $X=\left[\left(\right.\right.$ at $\% X_{\text {sample }}$ - at $\% X_{\text {control }}$ ) / 100] $\times$ [concentration $\mathrm{N}$ or C in sample], with $X$ representing ${ }^{15} \mathrm{~N}$ or ${ }^{13} \mathrm{C}$. at $\% X$ was calculated from $\delta X$ as: at $\% X=\left[100 \times R_{\text {standard }} \times\left(\delta X_{\text {sample }} / 1000\right)+1\right]$ $/\left[1+R_{\text {standard }} \times\left(\delta X_{\text {sample }} / 1000\right)+1\right]$, and $\delta \mathrm{X}$ was calculated as: $\delta X(\%)=\left[\left(R_{\text {sample }} / R_{\text {standard }}\right)-1\right] \times 1000$. For ${ }^{15} \mathrm{~N}$, $R={ }^{15} \mathrm{~N} /{ }^{14} \mathrm{~N}$ and atmospheric $\mathrm{N}_{2}$ was used as standard. For ${ }^{13} \mathrm{C}, R={ }^{13} \mathrm{C} /{ }^{12} \mathrm{C}$ and Vienna Pee Dee Belemnite was used as standard. $\delta^{13} \mathrm{C}$ values for the HAAs were corrected for addition of extra $\mathrm{C}$ during derivatization as described by Veuger et al. (2006). Unlabeled sediment was used as a control sample to determine the natural abundance of ${ }^{15} \mathrm{~N}$ and ${ }^{13} \mathrm{C}$.

D-Ala concentrations and excess ${ }^{15} \mathrm{~N}$ and ${ }^{13} \mathrm{C}$ in D-Ala were corrected for hydrolysis-induced racemization empirically by subtracting $1.7 \%$ of the concentration of (or excess ${ }^{15} \mathrm{~N}$ or ${ }^{13} \mathrm{C}$ in) L-Ala from the concentration of (or excess ${ }^{15} \mathrm{~N}$ or ${ }^{13} \mathrm{C}$ in) D-Ala. The $1.7 \%$ is the average fraction of L-Ala being converted to D-Ala during hydrolysis under the used conditions (Kaiser \& Benner 2005, update of Veuger et al. 2005).

Excess ${ }^{15} \mathrm{~N}$ in $\mathrm{D}$-Ala is also expressed relative to that in L-Ala as the excess ${ }^{15} \mathrm{~N}$ D/L-Ala ratio, which was calculated as: [excess ${ }^{15} \mathrm{~N}$ in D-Ala] / [excess ${ }^{15} \mathrm{~N}$ in L-Ala], using the measured excess ${ }^{15} \mathrm{~N}$ in $\mathrm{D}$-Ala (i.e. not corrected for racemization). Instead, the racemization background $(0.015-0.02)$ is indicated graphically. The bacterial contribution to total microbial ${ }^{15} \mathrm{~N}$ incorporation was calculated from the excess ${ }^{15} \mathrm{~N}$ D/L-Ala ratios as: bacterial contribution $(\%)=$ (excess ${ }^{15} \mathrm{~N}$ D/L-Ala - 0.017) / (bacterial D/L-Ala $0.017) \times 100$, where 0.017 represents the racemization background. Since the D/L-Ala ratio of natural bacterial communities ranges between 0.05 and $\sim 0.1$ (update of Veuger 2005), bacterial D/L-Ala ratios of 0.05 and 0.1 were used to derive a maximum and minimum estimate of the bacterial contribution respectively (see Fig. 2A). 


\section{RESULTS}

\section{Sediment properties}

The organic carbon (OC) content of the sediment was $2.0 \pm 0.1 \mathrm{wt}$ (weight) $\%\left(1.7 \pm 0.1 \mathrm{mmol} \mathrm{C} \mathrm{g}^{-1}\right)$ for $\mathrm{BMA}+$ sediment and $1.6 \pm 0.1 \mathrm{wt} \%(1.3 \pm 0.1 \mathrm{mmol} \mathrm{C}$ $\mathrm{g}^{-1}$ ) for BMA- sediment. The nitrogen content of the sediment was $0.26 \pm 0.02 \mathrm{wt} \%\left(0.16 \pm 0.05 \mathrm{mmol} \mathrm{C} \mathrm{g}^{-1}\right)$ and $0.19 \pm 0.02 \mathrm{wt} \%\left(0.13 \pm 0.03 \mathrm{mmol} \mathrm{C}^{-1}\right)$ for BMA+ and BMA- sediment, respectively. The corresponding $\mathrm{C} / \mathrm{N}$ ratio (moles OC/moles $\mathrm{N}$ ) was $10 \pm 2$ for the sediment from both sites. THAA concentrations (summed concentrations of individual HAAs) were $100 \pm 14 \mu \mathrm{mol} \mathrm{AA} \mathrm{g}{ }^{-1}$ in BMA+ sediment and $64 \pm$ $6 \mu \mathrm{mol} \mathrm{AA} \mathrm{g}{ }^{-1}$ in BMA- sediment. THAA-C made up 24 and $19 \%$ of total OC in the BMA+ and BMA- sediment, respectively, and THAA-N made up 66 and $51 \%$ of total $\mathrm{N}$ in the BMA+ and BMA- sediment, respectively. D-Ala concentrations (corrected for hydrolysisinduced racemization) were very similar for BMA+ and BMA- $\left(0.29 \pm 0.06 \mu \mathrm{mol} \mathrm{g}{ }^{-1}\right)$, while D/L-Ala ratios (not corrected for racemization) were $0.038 \pm 0.001$ for $\mathrm{BMA}+$ sediment and $0.050 \pm 0.005$ for $\mathrm{BMA}-$ sediment.

\section{Microbial community composition}

Bacterial biomass was estimated from concentrations of the bacteria-specific PLFAs i14:0, i15:0 and a15:0 assuming that $\mathrm{C}$ in i14:0, i15:0 and a15:0 makes up $12 \%$ of total bacterial PLFA-C and that total bacterial PLFA-C is $6 \%$ of total bacterial biomass-C (Middelburg et al. 2000). Resulting estimates were 24 and $22 \mu \mathrm{mol} \mathrm{C} \mathrm{g}{ }^{-1}$ for BMA+ and BMA- sediment, respectively. Algal biomass was estimated from concentrations of chlorophyll a $(\mathrm{chl}$ a) assuming a $\mathrm{C} / \mathrm{chl}$ a ratio of 50. Average chl a concentrations were $118 \mu^{-1} \mathrm{~g}^{-1}$ for $\mathrm{BMA}+$ sediment and $73 \mu \mathrm{g} \mathrm{g^{-1 }}$ for BMA- sediment. Resulting estimates of total algal biomass were $492 \mu \mathrm{mol} \mathrm{C} \mathrm{g}{ }^{-1}$ for BMA+ and $306 \mu \mathrm{mol} \mathrm{C} \mathrm{g}^{-1}$ for BMA-. The sediment showed a high abundance of the diatom pigment fucoxanthin with a fucoxanthin/chl a ratio of $\sim 0.25$ for sediment from both sites, and the diatom-specific PLFA 20:5 $\omega 3$ made up a large fraction $(18 \pm 2 \%)$ of the total PLFA pool in the sediment. Concentrations of the cyanobacterial pigment zeaxanthin were below the limit of detection.

\section{${ }^{15} \mathrm{~N}$ in bulk sediment and THAAs}

Addition of the ${ }^{15} \mathrm{~N}$-labeled substrates to the sediments resulted in clear ${ }^{15} \mathrm{~N}$ enrichment of the bulk sediment and HAAs, including D-Ala, with $\delta^{15} \mathrm{~N}$ values up to $\sim 250 \%$ (natural abundance was $\sim 20 \%$ o). Trends in excess ${ }^{15} \mathrm{~N}$ in bulk sediment and THAAs over time were very similar for BMA+ and BMAslurries, but showed a clear difference between slurries incubated with urea and those incubated with the AA-mix (Fig. 1). In the AA-mix incubations (Fig. 1A), bulk excess ${ }^{15} \mathrm{~N}$ was high $\left(\sim 60 \mathrm{nmol}{ }^{15} \mathrm{~N}\right.$ $\mathrm{g}^{-1}$ ) almost directly (10 to $15 \mathrm{~min}$ ) after addition of the labeled AA-mix, and remained at this level during the entire $24 \mathrm{~h}$ incubation period. This level corresponded to the total concentration of $\mathrm{AA}-{ }^{15} \mathrm{~N}$ added to the sediment. Conversely, excess ${ }^{15} \mathrm{~N}$ in THAAs was initially very low, then rapidly increased during the first $4 \mathrm{~h}$ and leveled off to values that represented

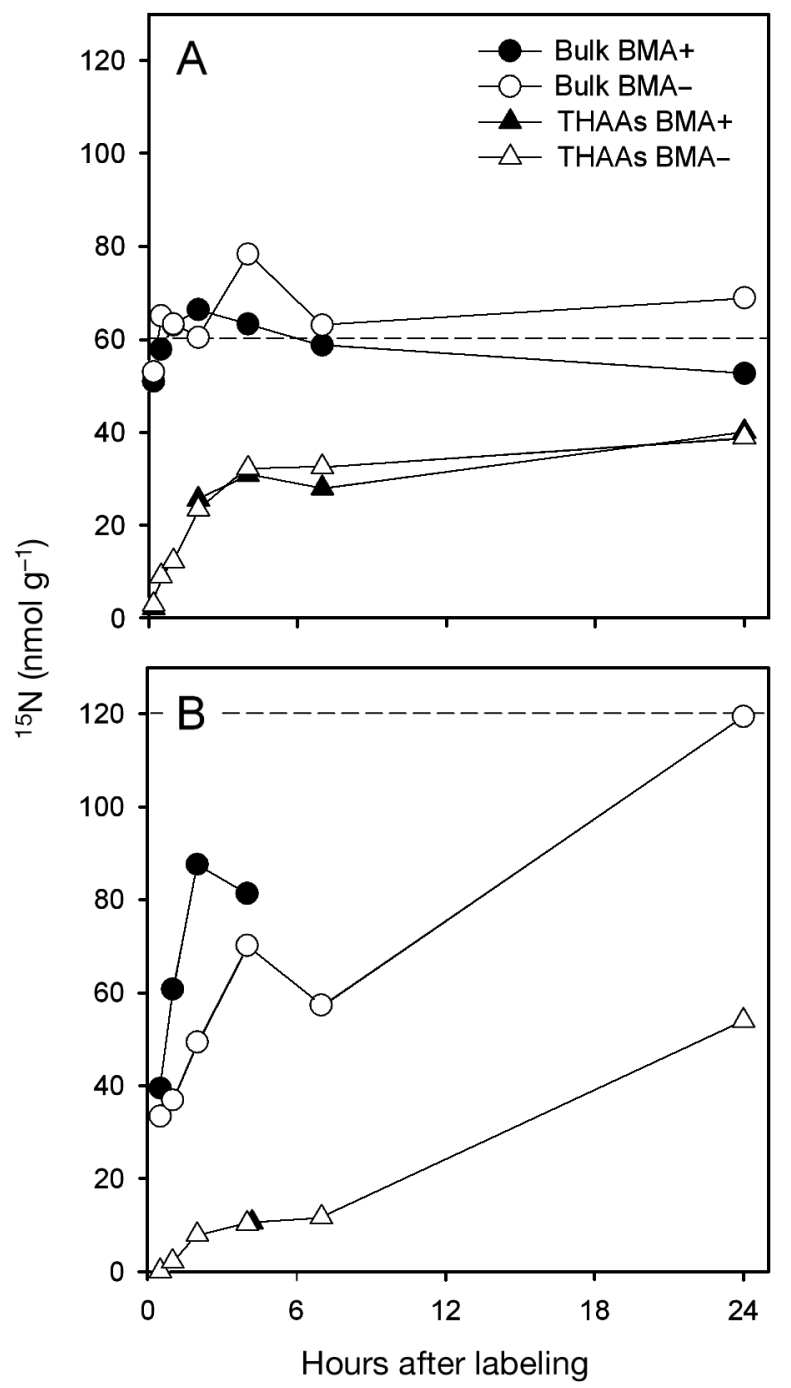

Fig. 1. Excess ${ }^{15} \mathrm{~N}$ in bulk sediment and THAAs (summed excess ${ }^{15} \mathrm{~N}$ in individual HAAs [hydrolysable amino acids]) for incubations with (A) the AA-mix (amino acid mixture) and (B) urea. BMA+ and BMA- refer to sediment from the first and second sites, respectively. Dashed lines indicate total concentrations of added ${ }^{15} \mathrm{~N}$ 
48 to $52 \%$ of bulk excess ${ }^{15} \mathrm{~N}$ after $7 \mathrm{~h}$ and 57 to $76 \%$ after $24 \mathrm{~h}$. In the urea incubations (Fig. 1B), bulk excess ${ }^{15} \mathrm{~N}$ after $0.5 \mathrm{~h}$ was $\sim 40 \mathrm{nmol}{ }^{15} \mathrm{~N} \mathrm{~g}^{-1}$, while excess ${ }^{15} \mathrm{~N}$ in THAAs was negligibly low. In the BMA- incubations with urea, both bulk ${ }^{15} \mathrm{~N}$ and ${ }^{15} \mathrm{~N}$ in THAAs increased linearly $\left(3.4 \mathrm{nmol}{ }^{15} \mathrm{~N} \mathrm{~g}^{-1} \mathrm{~h}^{-1}\right.$ with $\mathrm{R}^{2}$ of 0.90 for bulk ${ }^{15} \mathrm{~N}$, and $2.2 \mathrm{nmol}{ }^{15} \mathrm{~N} \mathrm{~g}^{-1} \mathrm{~h}^{-1}$ with $\mathrm{R}^{2}$ of 0.97 for ${ }^{15} \mathrm{~N}$-THAAs) over the $24 \mathrm{~h}$ incubation period (no data for BMA+ after 7 and $24 \mathrm{~h}$ ). After $24 \mathrm{~h}$, bulk excess ${ }^{15} \mathrm{~N}$ in the BMA- sediment was similar to the total added amount of urea- ${ }^{15} \mathrm{~N}$, and excess ${ }^{15} \mathrm{~N}$ in THAAs was $45 \%$ of bulk excess ${ }^{15} \mathrm{~N}$. In all incubations, all individual HAAs showed a similar level of ${ }^{15} \mathrm{~N}$ enrichment and the relative composition of the ${ }^{15} \mathrm{~N}$-labeled THAA pools was similar to that of the total THAA pool (i.e. total concentrations in the sediment) (data not shown).

\section{${ }^{15} \mathrm{~N}$ in D-Ala}

For BMA- sediment, excess ${ }^{15} \mathrm{~N}$ D/L-Ala ratios (Fig. 2A) were initially high (up to $\sim 0.08$ ) but rapidly decreased to substantially lower values (0.030 to 0.035 ) after $4 \mathrm{~h}$. After $24 \mathrm{~h}$, values for urea incubations had decreased further, while values for AA-mix incubations remained at the same level. Values for the BMA+ sediment incubated with the AA-mix were near or at racemization background (except for a somewhat higher value after $2 \mathrm{~h}$ ). Therefore, excess ${ }^{15} \mathrm{~N}$ in D-Ala could not be quantified properly for these samples. ${ }^{15} \mathrm{~N}$ incorporation into D-Ala in BMA- sediment incubated with the AA-mix appears to have been very rapid $\left(\sim 0.24 \mathrm{nmol}{ }^{15} \mathrm{~N} \mathrm{~g}^{-1} \mathrm{~h}^{-1}\right)$ during the first 10 to $15 \mathrm{~min}$, while incorporation was substantially lower during the following $24 \mathrm{~h}\left(\sim 0.001 \mathrm{nmol}{ }^{15} \mathrm{~N} \mathrm{~g}^{-1} \mathrm{~h}^{-1}, \mathrm{R}^{2}=0.96\right)$ (Fig. 2B). Conversely, BMA- sediment incubated with urea showed a more or less linear increase in excess ${ }^{15} \mathrm{~N}$ in D-Ala over time $\left(\sim 0.025 \mathrm{nmol}{ }^{15} \mathrm{~N} \mathrm{~g}^{-1} \mathrm{~h}^{-1}, \mathrm{R}^{2}=\right.$ $0.67)$. The estimated bacterial contribution to total microbial ${ }^{15} \mathrm{~N}$ incorporation calculated from excess ${ }^{15} \mathrm{~N}$ D/L-Ala ratios (Fig. 2A) for BMA- sediment was high (70 to $100 \%$ ) early in the incubations, but substantially lower (16 to $55 \%$ ) after 4 to $7 \mathrm{~h}$. After $24 \mathrm{~h}$, the bacterial contribution was 19 to $48 \%$ for BMA- incubations with the AA-mix, and only 6 to $15 \%$ for those with urea.

\section{${ }^{13} \mathrm{C}$ in bulk sediment and HAAs}

Sediment incubated with the AA-mix showed substantial ${ }^{13} \mathrm{C}$ enrichment (Fig. 3A) with trends over time similar to those for excess ${ }^{15} \mathrm{~N}$ (Fig. 1A). In the sediment incubated with urea, ${ }^{13} \mathrm{C}$ enrichment was low, with no
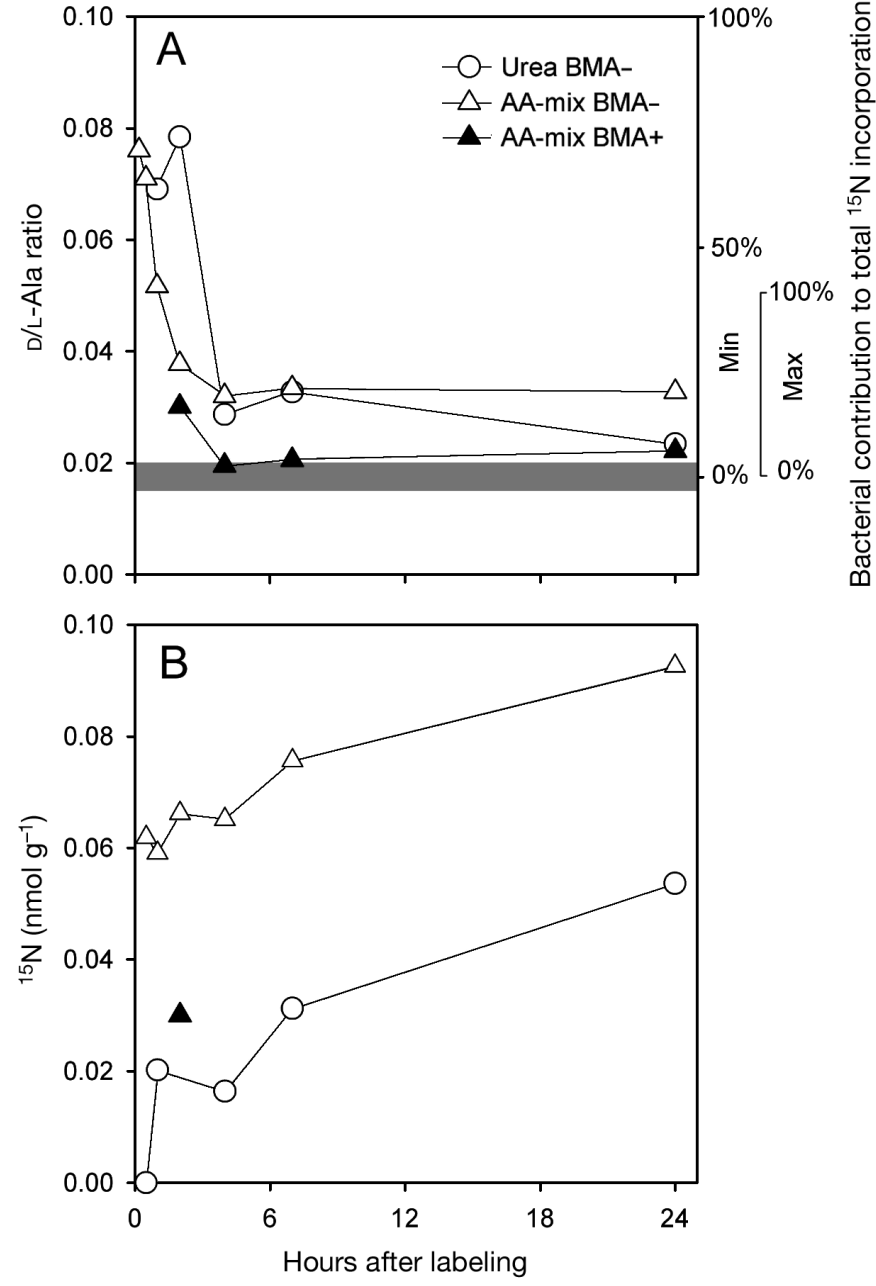

Fig. 2. (A) Excess ${ }^{15} \mathrm{~N}$ D/L-Ala ratios (excess ${ }^{15} \mathrm{~N}$ in D-Ala/ excess ${ }^{15} \mathrm{~N}$ in L-Ala) and corresponding minimum and maximum estimates of the bacterial contribution to total ${ }^{15} \mathrm{~N}$ incorporation and (B) excess ${ }^{15} \mathrm{~N}$ in D-Ala (corrected for hydrolysis induced racemization). Grey bar indicates racemization background. No excess ${ }^{15} \mathrm{~N}$ in $\mathrm{D}$-Ala is presented for BMA+ samples with excess ${ }^{15} \mathrm{~N}$ D/L-Ala ratios near or at racemization background. Ala: alanine; for other abbreviations, see Fig. 1

clear trend over time for bulk excess ${ }^{13} \mathrm{C}$ and a small excess ${ }^{13} \mathrm{C}$ in THAAs $\left(\sim 5 \mathrm{nmol}{ }^{13} \mathrm{C} \mathrm{g}^{-1}\right.$ ) (Fig. 3B). ${ }^{13} \mathrm{C}$ enrichment of D-Ala was below the limit of detection for urea incubations and very low for AA-mix incubations, with excess ${ }^{13} \mathrm{C}$ D/L-Ala ratios close to racemization background. Therefore, excess ${ }^{13} \mathrm{C}$ in D-Ala could not be quantified properly.

\section{${ }^{15} \mathrm{~N}$ versus ${ }^{13} \mathrm{C}$ in bulk sediment and HAAs}

For the AA-mix incubations, excess ${ }^{13} \mathrm{C} /{ }^{15} \mathrm{~N}$ ratios of the bulk sediment were 1 to 1.5 during the first hour and 1.5 to 2 for the rest of the incubation period 


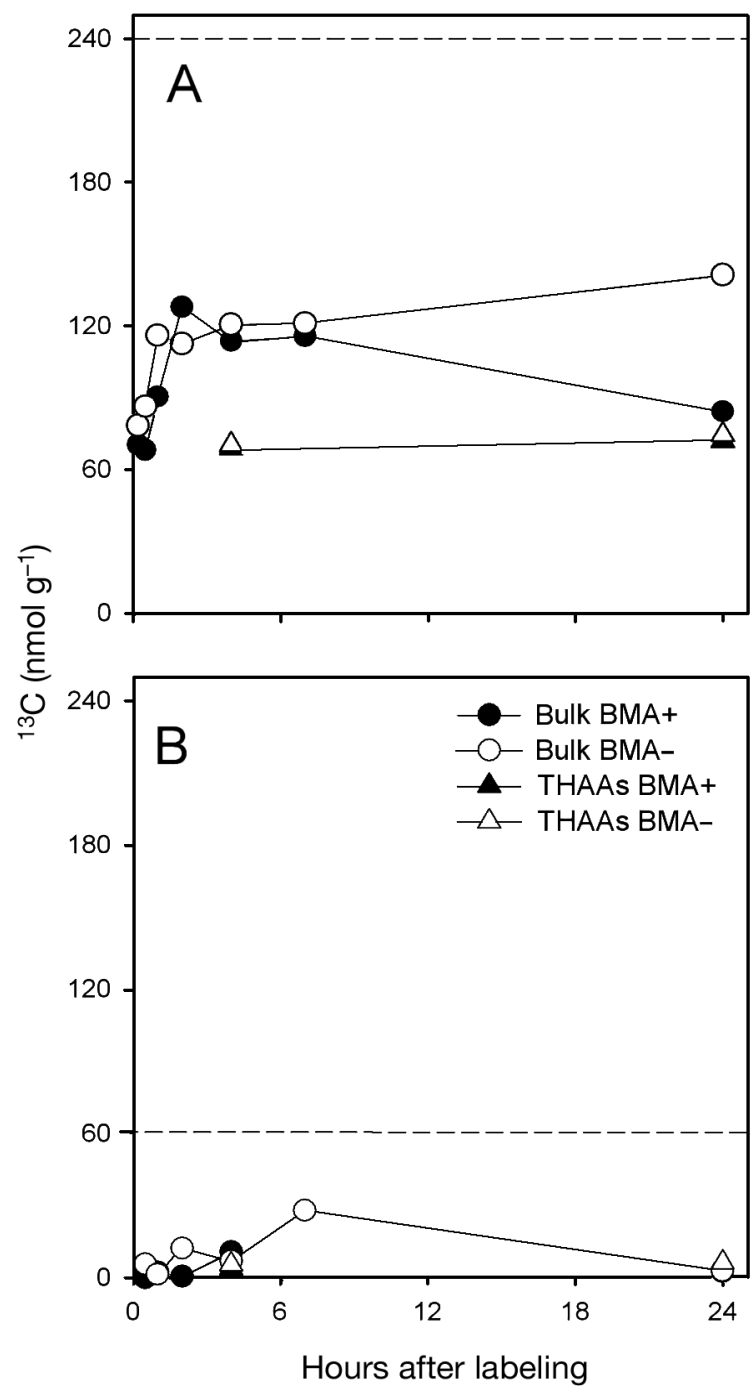

Fig. 3. Excess ${ }^{13} \mathrm{C}$ in bulk sediment and THAAs (summed excess ${ }^{13} \mathrm{C}$ in individual HAAs) for incubations with (A) the AA-mix and (B) urea. Dashed lines indicate total concentrations of added ${ }^{13}$ C. For abbreviations, see Fig. 1

(Fig. 4A). Excess ${ }^{13} \mathrm{C} /{ }^{15} \mathrm{~N}$ ratios for the THAAs (Fig. 4B) were similar to that for the bulk sediment $(\sim 2)$. Values were all clearly lower than the excess ${ }^{13} \mathrm{C} /{ }^{15} \mathrm{~N}$ ratio of the added AA-mix ( 4). For the urea incubations, excess ${ }^{13} \mathrm{C} /{ }^{15} \mathrm{~N}$ ratios of the bulk sediment ranged between 0.01 and 0.25 (with the exception of BMAafter $7 \mathrm{~h}$ ), and lowest values (0.02 to 0.04 ) occurred after $24 \mathrm{~h}$ (Fig. 4A). The excess ${ }^{13} \mathrm{C} /{ }^{15} \mathrm{~N}$ ratio for THAAs (Fig. 4B) after $4 \mathrm{~h}$ was 0.4 to 0.5 , which is similar to the ${ }^{13} \mathrm{C} /{ }^{15} \mathrm{~N}$ ratio of the added urea $(0.5)$. After $24 \mathrm{~h}$, the excess ${ }^{13} \mathrm{C} /{ }^{15} \mathrm{~N}$ ratio for the THAAs was substantially lower (0.1). No excess ${ }^{13} \mathrm{C} /{ }^{15} \mathrm{~N}$ ratio is presented for DAla because excess ${ }^{13} \mathrm{C}$ in D-Ala could not be quantified properly.

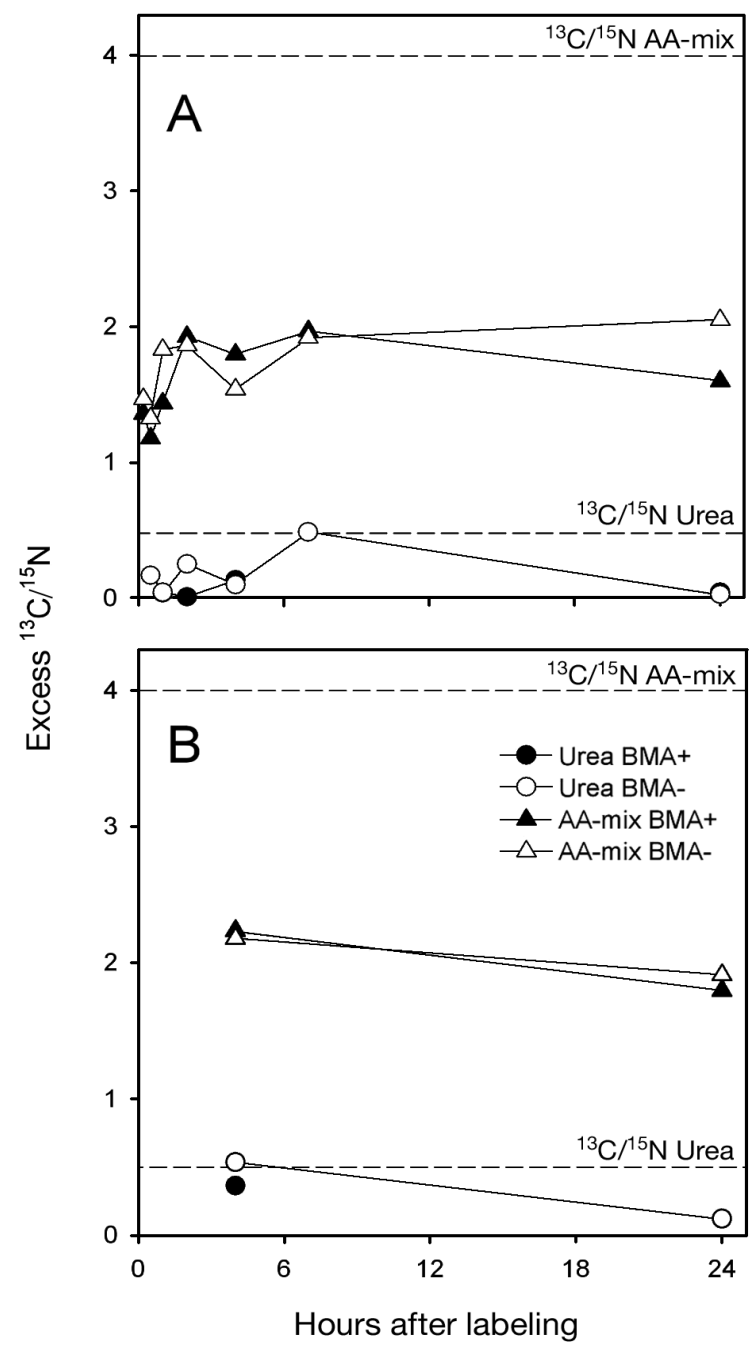

Fig. 4. Excess ${ }^{13} \mathrm{C} /{ }^{15} \mathrm{~N}$ ratio of (A) bulk sediment and (B) THAAs. Dashed lines indicate ${ }^{13} \mathrm{C} /{ }^{15} \mathrm{~N}$ ratios of added substrates. For abbreviations, see Fig. 1

\section{${ }^{13} \mathrm{C}$-DIC production}

For both substrates, part of the added ${ }^{13} \mathrm{C}$ was recovered as ${ }^{13} \mathrm{C}$-DIC in the water (Fig. 5). Unfortunately, it was not possible to quantify the total amount of ${ }^{13} \mathrm{C}$ that was recovered as ${ }^{13} \mathrm{C}$-DIC because the experiment was performed in open bottles, which allowed loss of ${ }^{13} \mathrm{C}$-DIC by diffusion. However, semi-quantitative interpretation of Fig. 5 shows that ${ }^{13} \mathrm{C}$-DIC production was substantially higher in the incubations with urea than in those with the AA-mix. This difference becomes even larger when taking into account that the $\mathrm{C}$-content of the AA-mix was about 4 times higher than that of urea. Highest excess ${ }^{13} \mathrm{C}$-DIC values were reached after 4 to $7 \mathrm{~h}$ for urea and after 2 to $4 \mathrm{~h}$ for the AA-mix. Production of ${ }^{13} \mathrm{C}$-DIC from ${ }^{13} \mathrm{C}$-urea was more rapid in BMA+ sediment than in BMA-sediment. 


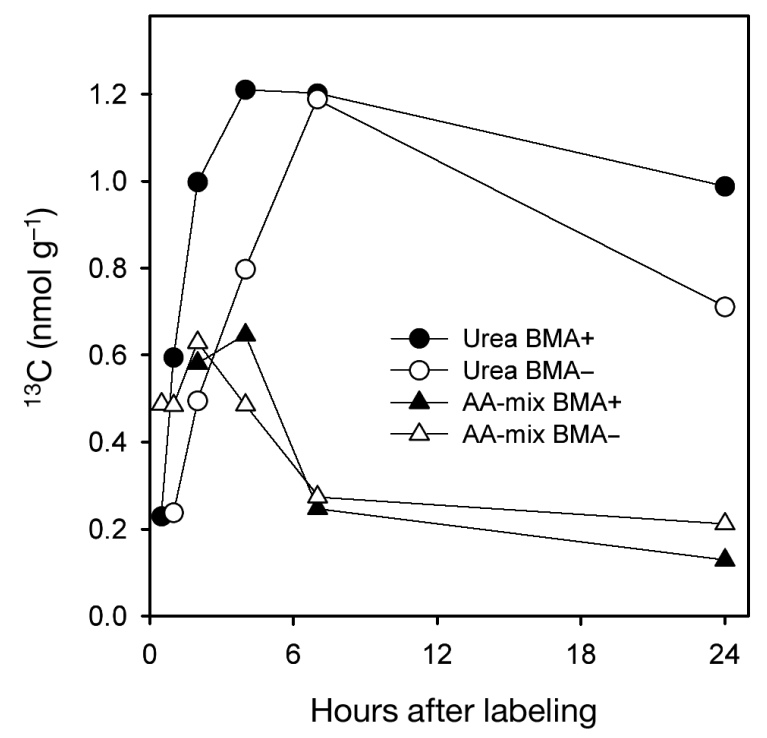

Fig. 5. Excess ${ }^{13} \mathrm{C}$ in dissolved inorganic carbon in water, expressed per gram dry sediment. For abbreviations, see Fig. 1

\section{DISCUSSION}

\section{Bulk ${ }^{15} \mathrm{~N}$ and total ${ }^{15} \mathrm{~N}$ incorporation: amino acids}

To aid the interpretation of our results, an overview of the ${ }^{15} \mathrm{~N}$ pools in the sediment is provided in Fig. 6. Bulk ${ }^{15} \mathrm{~N}$ did not include dissolved ${ }^{15} \mathrm{~N}$-labeled material because overlying water and pore water were removed from the sediment after incubation. Samples for ${ }^{15} \mathrm{~N}-\mathrm{HAA}$ analysis were washed with water and $2 \mathrm{M}$ $\mathrm{HCl}$ prior to hydrolysis, which removed dissolved, sediment-bound and intracellular material, leaving the ${ }^{15} \mathrm{~N}-\mathrm{HAAs}$ from biomass only (see Veuger et al. 2005). This also means that ${ }^{15} \mathrm{~N}$-THAA results for the AA-mix incubations were not biased by the added ${ }^{15} \mathrm{~N}$-labeled amino acids (dissolved in pore water or bound to sediment), which was confirmed by the very low excess ${ }^{15} \mathrm{~N}$ in THAAs in the incubations that were stopped almost directly (10 to $15 \mathrm{~min}$ ) after addition of the AAmix (Fig. 1B). It should also be noted that presented results concern concentrations of excess ${ }^{15} \mathrm{~N}$ and ${ }^{13} \mathrm{C}$ only. Ambient urea and DFAAs were not taken into account because concentrations of added $\left({ }^{15} \mathrm{~N}\right.$ and ${ }^{13} \mathrm{C}$ labeled) urea and amino acids were 5 to 8 times higher than ambient concentrations of both urea and DFAAs in the pore water.

Bulk excess ${ }^{15} \mathrm{~N}$ in the AA-mix incubations remained stable throughout the entire sampling period at a level representing the concentration of total added ${ }^{15} \mathrm{~N}$ (Fig. 1). Combined with the very low excess ${ }^{15} \mathrm{~N}$ in microbial biomass (THAAs) at the beginning of the incubation period, this indicates that all ${ }^{15} \mathrm{~N}$ from the AAmix was rapidly bound to the sediment and/or taken

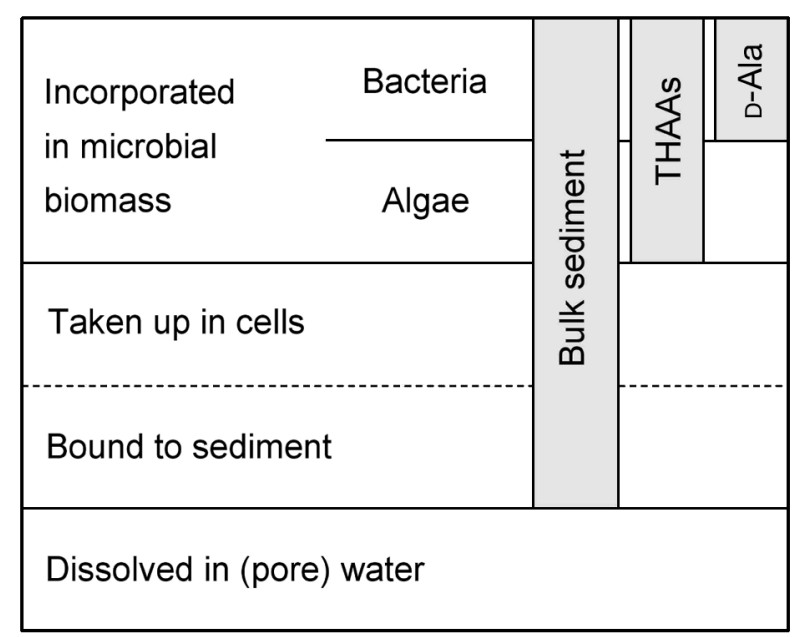

Fig. 6. Overview of different ${ }^{15} \mathrm{~N}$ pools in sediment incubations. Dashed line indicates no proper distinction between these pools. THAA: total hydrolysable amino acids; D-Ala: D-alanine

up into microbial cells. Unfortunately, our data do not allow distinction between these 2 pools. This sediment-bound and/or intracellular ${ }^{15} \mathrm{~N}$ may have comprised ${ }^{15} \mathrm{~N}$-amino acids from the added AA-mix. However, the rapid uncoupling of ${ }^{15} \mathrm{~N}$ and ${ }^{13} \mathrm{C}$ from the AA-mix (Fig. 4) indicates that this pool also included ${ }^{15} \mathrm{NH}_{4}{ }^{+}$resulting from extracellular oxidation of the ${ }^{15} \mathrm{~N}$-amino acids (see Fig. 7 and 'Discussion', section ${ }^{115} \mathrm{~N}$ versus ${ }^{13} \mathrm{C}$ :amino acids'). The rapid increase in excess ${ }^{15} \mathrm{~N}$ in THAAs (Fig. 1B) during the first $4 \mathrm{~h}$ reflects rapid incorporation of ${ }^{15} \mathrm{~N}$ into microbial biomass. The subsequent leveling off of ${ }^{15} \mathrm{~N}$ incorporation after $4 \mathrm{~h}$ likely resulted from depletion of the available ${ }^{15} \mathrm{~N}$ pool $\left({ }^{15} \mathrm{~N}\right.$-amino acids and/or $\left.{ }^{15} \mathrm{NH}_{4}{ }^{+}\right)$. This is confirmed by the large fraction of bulk excess ${ }^{15} \mathrm{~N}$ present in THAAs after $24 \mathrm{~h}$ (57\% for BMA- and $76 \%$ for BMA+). This fraction is very similar to the THAA content of microbial biomass (50 to $60 \%$ for bacterial biomass [Simon \& Azam 1989, Cowie \& Hedges 1992] and 60 to $80 \%$ for algal biomass [Cowie \& Hedges 1992]), indicating that (nearly) all added ${ }^{15} \mathrm{~N}$ had been incorporated into microbial biomass. The relatively low value for the BMAincubations after $24 \mathrm{~h}$ may be related to the relatively high contribution by bacteria (with a lower THAAs content than algae) to the ${ }^{15} \mathrm{~N}$ incorporation in these incubations (see Fig. 2 and 'Discussion', section 'Bacterial contribution to total microbial ${ }^{15} \mathrm{~N}$ incorporation').

\section{Bulk ${ }^{15} \mathrm{~N}$ and total ${ }^{15} \mathrm{~N}$ incorporation: urea}

Unlike for the AA-mix incubations, bulk excess ${ }^{15} \mathrm{~N}$ at the beginning of the urea incubations was only onethird of the total added concentration of urea- ${ }^{15} \mathrm{~N}$. 
Since ${ }^{15} \mathrm{~N}$ incorporation into microbial biomass (reflected by ${ }^{15} \mathrm{~N}$ in THAAs) at this time was negligible, this pool must have consisted of ${ }^{15} \mathrm{~N}$ bound to the sediment and/or taken up into cells. The rapid and strong uncoupling between urea- ${ }^{15} \mathrm{~N}$ and urea- ${ }^{13} \mathrm{C}$ in the bulk sediment (Fig. 4A) indicates that the ${ }^{15} \mathrm{~N}$ was not bound to the sediment as urea but mostly as ${ }^{15} \mathrm{NH}_{4}{ }^{+}$ resulting from rapid metabolization of the labeled urea (see Fig. 7 and 'Discussion', section ${ }^{15} \mathrm{~N}$ versus ${ }^{13} \mathrm{C}$ :urea'). The subsequent increase in bulk ${ }^{15} \mathrm{~N}$ during the $24 \mathrm{~h}$ incubation period was due to ${ }^{15} \mathrm{~N}$ incorporation into microbial biomass, as reflected by the parallel increase in ${ }^{15} \mathrm{~N}$-THAAs. After $24 \mathrm{~h}$, all added ${ }^{15} \mathrm{~N}$ was recovered in the bulk excess ${ }^{15} \mathrm{~N}$, which indicates that two-thirds of the added ${ }^{15} \mathrm{~N}$ that was not rapidly bound to the sediment and/or taken up into cells at the beginning of the incubations (i.e. ${ }^{15} \mathrm{~N}$-urea and/or ${ }^{15} \mathrm{NH}_{4}{ }^{+}$ dissolved in [pore] water) had been incorporated into microbial biomass. The fraction of bulk excess ${ }^{15} \mathrm{~N}$ present in THAAs in the urea incubations after $24 \mathrm{~h}(45 \%)$ was somewhat lower than that in the AA-mix incubations, indicating that a somewhat smaller, but still substantial, fraction (56 to $75 \%$ ) of urea- ${ }^{15} \mathrm{~N}$ had been incorporated into microbial biomass. The remaining fraction must have consisted of ${ }^{15} \mathrm{~N}$ bound to the sediment and/or taken up into cells (as ${ }^{15} \mathrm{~N}$-urea and/or $\left.{ }^{15} \mathrm{NH}_{4}{ }^{+}\right)$.

\section{Bacterial contribution to total microbial ${ }^{15} \mathbf{N}$ incorporation}

Until recently, it was impossible to trace ${ }^{15} \mathrm{~N}$ uptake and incorporation by specific groups within the total microbial community. Application of a new method that combines ${ }^{15} \mathrm{~N}$ labeling with analysis of ${ }^{15} \mathrm{~N}$ in the bacterial biomarker D-Ala (Veuger et al. 2005) in the present study allowed us to assess the contribution of bacteria to total microbial ${ }^{15} \mathrm{~N}$ incorporation. The best indication of this bacterial contribution is provided by the excess ${ }^{15} \mathrm{~N}$ D/L-Ala ratio (Fig. 2A), where D-Ala is specific for bacteria while L-Ala is a common protein amino acid that makes up a stable fraction of the THAA pool of all organisms. For the present study it was assumed that ${ }^{15} \mathrm{~N}$ incorporation into fauna was negligible because this incorporation normally occurs via grazing, which causes a delay in ${ }^{15} \mathrm{~N}$ incorporation into fauna of $>24 \mathrm{~h}$ (Veuger et al. 2007). Therefore, the excess ${ }^{15} \mathrm{~N}$ D/L-Ala ratio in the present study provides a direct indication of the bacterial contribution to total microbial (bacteria + algae) ${ }^{15} \mathrm{~N}$ incorporation.

The main trend in excess ${ }^{15} \mathrm{~N}$ D/L-Ala ratios for BMAsediment involved high values early in the incubations followed by a rapid decrease to substantially lower val- ues after $4 \mathrm{~h}$. The initially high values of up to $\sim 0.08$ are within the range for D/L-Ala ratios of natural bacterial communities (0.05 to 0.1 , see update of Veuger et al. 2005), indicating that bacteria dominated initial ${ }^{15} \mathrm{~N}$ incorporation. This is reflected by the estimated bacterial contribution to total microbial incorporation of 70 to $100 \%$. In addition, values were well above the D/LAla ratio of $\sim 0.05$ for Gram-negative bacteria, which points to an additional contribution by Gram-positive bacteria that are characterized by substantially higher D/L-Ala ratios (see update of Veuger et al. 2005). The rapid decrease in excess ${ }^{15} \mathrm{~N}$ D/L-Ala ratios during the following hours to values well below bacterial D/L-Ala ratios indicates a strong decrease in the relative contribution by bacteria, and hence a strong increase in the relative contribution by algae to total microbial ${ }^{15} \mathrm{~N}$ incorporation. The excess ${ }^{15} \mathrm{~N}$ D/L-Ala ratio for BMA-sediment incubated with urea after $24 \mathrm{~h}$ close to the racemization background indicates that the bacterial contribution to total ${ }^{15} \mathrm{~N}$ incorporation after $24 \mathrm{~h}$ was very low (estimated bacterial contribution of 6 to $15 \%)$. Only in the case of BMA- sediment incubated with the AA-mix was the excess ${ }^{15} \mathrm{~N}$ D/L-Ala ratio of 0.033 after $24 \mathrm{~h}$ still well above racemization background, which points to a substantial bacterial contribution (19 to $48 \%$ ). These results suggest that bacteria incorporated $\mathrm{N}$ from urea and the AA-mix more rapidly than did algae (i.e. algae needed more time for uptake and incorporation), while algae were able to incorporate more ${ }^{15} \mathrm{~N}$ (i.e. larger incorporation capacity). The latter is consistent with our microbial biomass estimates that indicated that algal biomass in the sediment was an order of magnitude greater than bacterial biomass, and resulted in algal domination of total microbial ${ }^{15} \mathrm{~N}$ incorporation after $24 \mathrm{~h}$. Likely, the relatively large bacterial contribution to total microbial incorporation of ${ }^{15} \mathrm{~N}$ from the AA-mix after $24 \mathrm{~h}$ resulted from the relatively rapid ${ }^{15} \mathrm{~N}$ incorporation (i.e. most ${ }^{15} \mathrm{~N}$ from the AA-mix was incorporated during the first hours of incubation when bacteria were not yet outcompeted by algae). The measured fucoxanthin/chl a ratio of $\sim 0.25$ and the contribution of the diatom-specific PLFA 20:5 33 to the total PLFA pool are consistent with values from diatom cultures (Dijkman \& Kromkamp 2006), which indicates that the benthic microalgal community was dominated by diatoms and hence that nitrogen incorporation was also dominated by diatoms. In comparison with results for the BMAsediment, the limited data for the BMA+ sediment show relatively low excess ${ }^{15} \mathrm{~N}$ D/L-Ala ratios of relatively low excess, which point to a negligible bacterial contribution to total microbial ${ }^{15} \mathrm{~N}$ incorporation after $4 \mathrm{~h}$. These relatively low values for BMA+ are consistent with the relatively high algal biomass in this sediment. 
The algal domination of incorporation of $\mathrm{N}$ from amino acids and urea in the present study challenges the concept of DON being predominantly taken up by bacteria. This has some important implications for studies that use total uptake of labeled amino acids (usually leucine) as a measure for bacterial production (e.g. Kirchman et al. 1985). One of the main assumptions underlying this method is that amino acids are specifically taken up by bacteria. However, results from the present study clearly show that amino acid uptake in surface sediment can actually be dominated by algae. Substantial amino acid uptake by benthic microalgae was also reported by Linares \& Sundbäck (2006). This large algal contribution to total amino acid uptake actually provides a feasible explanation for discrepancies between estimates of bacterial production in the sediment of an intertidal mudflat in the Scheldt Estuary, where estimates based on leucine incorporation were an order of magnitude higher than those based on sediment oxygen consumption (van Oevelen et al. 2006). Hence, our results indicate that great care should be taken when converting uptake of labeled amino acids to bacterial production in studies on surface sediments as well as other systems characterized by relatively high algal biomass (e.g. phototrophic biofilms, algal blooms in the water column).

\section{${ }^{15} \mathrm{~N}$ versus ${ }^{13} \mathrm{C}$ : amino acids}

Incubations with the AA-mix showed clear incorporation of both ${ }^{15} \mathrm{~N}$ and ${ }^{13} \mathrm{C}$. However, the excess ${ }^{13} \mathrm{C} /{ }^{15} \mathrm{~N}$ ratios of the bulk sediment and THAAs (1.5 to 2) were substantially lower than that of the added AA-mix ( 4), which indicates preferential retention and incorporation of $\mathrm{AA}-{ }^{15} \mathrm{~N}$ over $\mathrm{AA}-{ }^{13} \mathrm{C}$. Moreover, the production of ${ }^{13} \mathrm{C}$-DIC (Fig. 5) confirms that part of the AA- ${ }^{13} \mathrm{C}$ was transformed to ${ }^{13} \mathrm{C}$-DIC. This uncoupled behavior of nitrogen and carbon from amino acids is consistent with results from previous studies on algal cultures (Algeus 1948, Stephens \& North 1971, Palenik \& Morel 1990, Antia et al. 1991) and coastal waters (Schell 1974, Mulholland et al. 2002, 2003, Andersson et al. 2006), and conversion of amino acid carbon to DIC in a coastal sediment was reported by Christensen \& Blackburn (1980).

The explanation for this uncoupling lies in the pathways for amino acid uptake and incorporation (Fig. 7). Incorporation of nitrogen and carbon from amino acids into microbial biomass can occur via 3 different pathways. (1) Direct uptake and incorporation: amino acids are taken up from the surrounding water into microbial cells as complete molecules that form readily available building blocks for production of new biomass, and therefore can be directly incorporated into proteinaceous

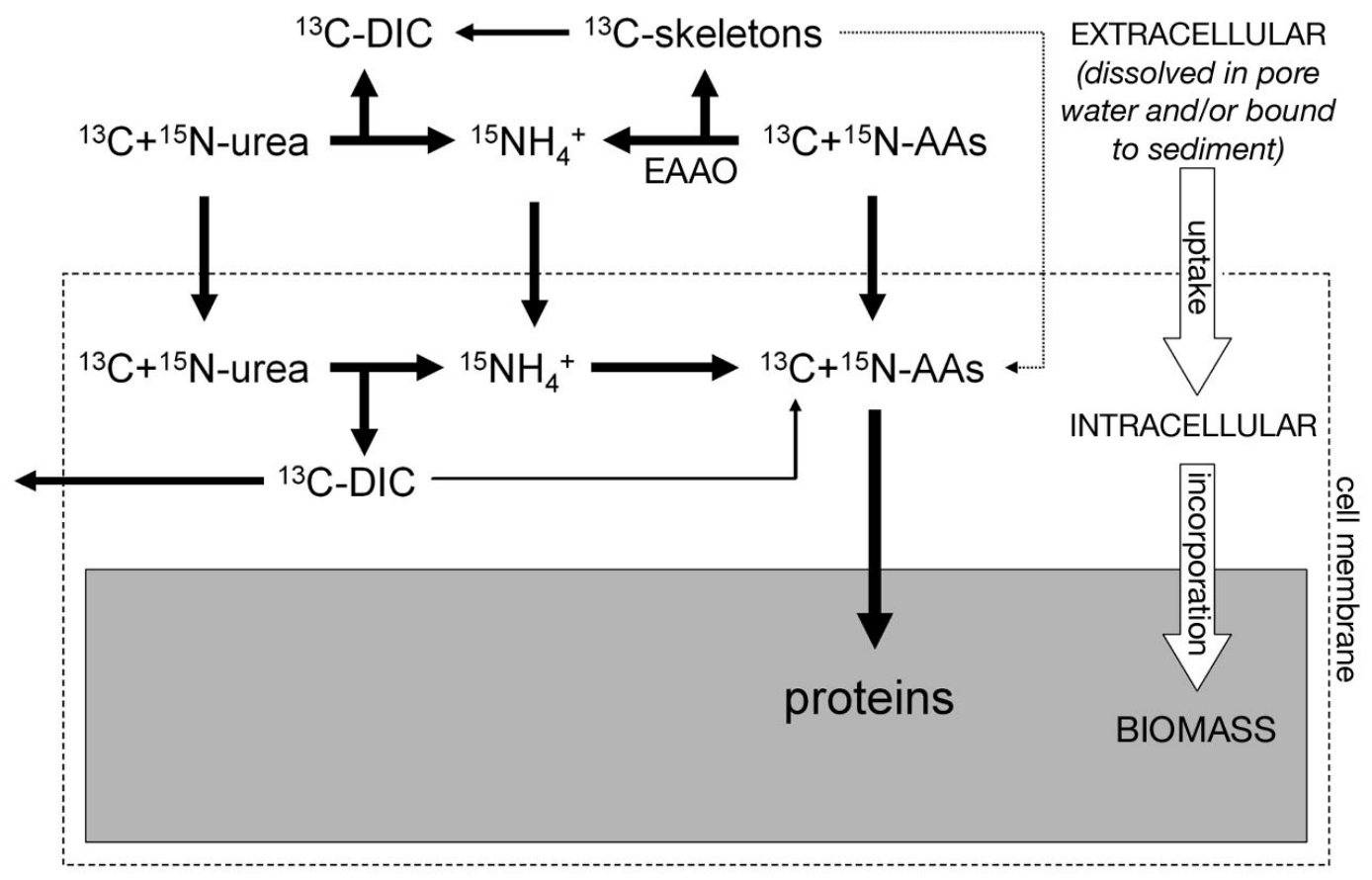

Fig. 7. Conceptual diagram of pathways for microbial uptake and incorporation of ${ }^{15} \mathrm{~N}$ and ${ }^{13} \mathrm{C}$ from dual labeled urea and amino acids. Arrow thickness indicates importance of pathway in present study. AAs: amino acids; EAAO: extracellular amino acid oxidation; DIC: dissolved inorganic carbon 
biomass. (2) Direct uptake into cells followed by transformation into other amino acids when the composition of the available amino acid pool does not reflect that of microbial biomass (Stephens \& North 1971). (3) Indirect uptake and incorporation via extracellular amino acid oxidation (EAAO). Amino acids are oxidized to $\mathrm{NH}_{4}{ }^{+}$, peroxide and $\mathrm{C}$-skeletons outside the cells after which the $\mathrm{NH}_{4}{ }^{+}$can be taken up and used as a nitrogen source for growth (Palenik \& Morel 1990, Antia et al. 1991, Pantoja \& Lee 1994, Mulholland et al. 1998).

The relatively low ${ }^{13} \mathrm{C} /{ }^{15} \mathrm{~N}$ ratio for the bulk sediment and THAAs may theoretically have resulted from preferential incorporation of amino acids with a low $\mathrm{C} / \mathrm{N}$ ratio such as $\operatorname{Arg}(\mathrm{C} / \mathrm{N}=1.5)$, His and Gly $(\mathrm{C} / \mathrm{N}=2)$. However, this is unlikely because Arg, His and Gly only made up a small fraction $(\sim 15 \%)$ of the total added AA-mix, while all amino acid-derived ${ }^{15} \mathrm{~N}$ was incorporated into microbial biomass. Moreover, substantial transformation of added amino acids to those with a $\mathrm{C} / \mathrm{N}$ ratio of 1.5 to 2 was very unlikely because the composition of the added AA-mix was similar to that of microbial biomass (Cowie \& Hedges 1992), meaning that the added AA-mix could directly be used for synthesis of new proteinaceous biomass. This was confirmed by the fact that all HAAs showed a similar level of ${ }^{15} \mathrm{~N}$ enrichment $\left(\delta^{15} \mathrm{~N}\right)$. Therefore, the uncoupled incorporation of ${ }^{15} \mathrm{~N}$ and ${ }^{13} \mathrm{C}$ from the AAmix was likely owing to EAAO, which resulted in efficient uptake of ${ }^{15} \mathrm{NH}_{4}{ }^{+}$and subsequent incorporation of the ${ }^{15} \mathrm{~N}$ into biomass. The ${ }^{13} \mathrm{C}$-skeletons produced by EAAO may have been used as a carbon source by heterotrophic bacteria and/or broken down to DIC, which is a potential carbon source for autotrophic algae. Both these pathways may have accounted for some of the ${ }^{13} \mathrm{C}$ incorporation; however, the latter seems unlikely because the ${ }^{13} \mathrm{C}$-DIC was probably lost by diffusion and/or diluted in a large background pool of ${ }^{12} \mathrm{C}$-DIC. Therefore, most of the ${ }^{13} \mathrm{C}$ incorporation in the AA-mix incubations was probably due to direct incorporation of the amino acids (with coupled incorporation of ${ }^{15} \mathrm{~N}$ ). The full incorporation of ${ }^{15} \mathrm{~N}$ combined with incorporation of $\sim 50 \%$ of the ${ }^{13} \mathrm{C}$ indicates that EAAO accounted for at least $50 \%$ of total microbial ${ }^{15} \mathrm{~N}$ incorporation.

These results are consistent with previous reports on the importance of EAAO in water column studies (Pantoja \& Lee 1994, Mulholland et al. 1998, 2002, 2003, Andersson et al. 2006) and for the first time show the importance of EAAO in microbial nitrogen incorporation in sediment. Although extracellular oxidation of amino acids and subsequent resynthesis of amino acids inside the cells seems inefficient, it may actually be more economical than direct uptake of intact amino acids, which requires more energy than uptake of $\mathrm{NH}_{4}{ }^{+}$(Antia et al. 1991 and references therein). More- over, EAAO may be a particularly efficient pathway for uptake and incorporation of amino acid nitrogen in sediments given the high cell densities (allowing efficient uptake of $\mathrm{NH}_{4}{ }^{+}$resulting from EAAO) and the relatively high concentrations of amino acids (dissolved free and combined) in sediments. EAAO generally seems to be associated with algae because only 1 study has reported EAAO activity in the bacterial size fraction (Pantoja \& Lee 1994). However, even when only algae are capable of EAAO, bacteria may still be able to use EAAO products as nitrogen and/or carbon substrates because these products are produced extracellularly. This may be especially relevant for systems like surface sediments and photosynthetic biofilms where bacteria and algae live in close association. Assessment of the role of EAAO in bacterial nitrogen uptake in the present study was not possible because nitrogen incorporation was dominated by algae.

\section{${ }^{15} \mathrm{~N}$ versus ${ }^{13} \mathrm{C}$ : urea}

In general, although all urea- ${ }^{15} \mathrm{~N}$ was incorporated into microbial biomass during the $24 \mathrm{~h}$ incubation period, the incorporation of urea- ${ }^{13} \mathrm{C}$ was much lower (Fig. 3B) and part of the ${ }^{13} \mathrm{C}$ was recovered as ${ }^{13} \mathrm{C}$-DIC (Fig. 5). As a result, corresponding excess ${ }^{13} \mathrm{C} /{ }^{15} \mathrm{~N}$ ratios were generally below that of the added urea (Fig. 4). These results are comparable with those of Lund \& Blackburn (1989), who measured production of ${ }^{14} \mathrm{C}$-DIC after addition of ${ }^{14} \mathrm{C}$-urea to a coastal marine sediment but no incorporation of ${ }^{14} \mathrm{C}$. Release of ${ }^{13} \mathrm{C}$ - or ${ }^{14} \mathrm{C}$-DIC following addition of ${ }^{13} \mathrm{C}$ - or ${ }^{14} \mathrm{C}$-urea was also observed for algal cultures (Price \& Harrison 1988, Antia et al. 1991 and references therein), bacteria from estuarine waters (Jørgensen 2006) and a natural planktonic microbial community (Tamminen \& Irmisch 1996). Moreover, uncoupled uptake of ${ }^{15} \mathrm{~N}$ and ${ }^{13} \mathrm{C}$ from dual-labeled urea has been reported for coastal waters (Mulholland et al. 2004, Fan \& Glibert 2005, Andersson et al. 2006).

The observed uncoupling of $\mathrm{C}$ and $\mathrm{N}$ from urea is consistent with the urea metabolization pathway (Fig. 7). In order for bacteria and algae to use urea as a nitrogen source for growth, urea first needs to be broken down to $\mathrm{NH}_{4}{ }^{+}$and DIC. Subsequently, the resulting $\mathrm{NH}_{4}{ }^{+}$can be used to synthesize amino acids for production of proteinaceous biomass, while the DIC may be used as a carbon source for photosynthesis (Price \& Harrison 1988, Antia et al. 1991). This urea metabolization pathway appears to be widespread because urease, the enzyme responsible for the breakdown of urea, is a common enzyme used by algae as well as bacteria (Price \& Harrison 1988, Mobley \& Hausinger 1989, Antia et al. 1991, Zehr \& Ward 2002). 
The rapid uncoupling between urea ${ }^{13} \mathrm{C}$ and ${ }^{15} \mathrm{~N}$ in the present study is consistent with the rapid metabolization of urea reported for algal cultures (Price \& Harrison 1988, Antia et al. 1991). During the first hours, only a small fraction of total added urea- ${ }^{15} \mathrm{~N}$ was incorporated into biomass (as indicated by ${ }^{15} \mathrm{~N}$ in THAAs). Therefore, the relatively high excess ${ }^{15} \mathrm{~N}$ (compared with ${ }^{13} \mathrm{C}$ ) in the bulk sediment during this period must have been due to a relatively strong retention of ${ }^{15} \mathrm{NH}_{4}{ }^{+}$by binding to the sediment and/or by selective uptake into microbial cells (see 'Discussion', section 'Bulk ${ }^{15} \mathrm{~N}$ and total ${ }^{15} \mathrm{~N}$ incorporation: urea'). Contrary to the preferential retention of ${ }^{15} \mathrm{~N}$ in the bulk sediment, the excess ${ }^{13} \mathrm{C} /{ }^{15} \mathrm{~N}$ ratio for the THAAs after $4 \mathrm{~h}$ (0.4 to 0.5 ) was very similar to that of the added urea (0.5), indicating that both ${ }^{15} \mathrm{NH}_{4}{ }^{+}$and ${ }^{13} \mathrm{C}$-DIC were used as sources of nitrogen and carbon, respectively, for growth during the first hours of incubation. The strong decrease in excess ${ }^{13} \mathrm{C} /{ }^{15} \mathrm{~N}$ ratios for bulk sediment and THAAs between 4 and $24 \mathrm{~h}$ (the period during which most of the added ${ }^{15} \mathrm{~N}$ was incorporated into microbial biomass) may have been due to light limitation during this period. Since ${ }^{13} \mathrm{C}$-DIC could not be fixed by photoautotrophic algae in the dark (overnight), the remaining ${ }^{13} \mathrm{C}$-DIC was probably lost from the sediment by diffusion. Although incorporation of ${ }^{15} \mathrm{~N}$ from ${ }^{15} \mathrm{NH}_{4}{ }^{+}$(derived from ${ }^{15} \mathrm{~N}$-urea) may also have been lower in the dark, ${ }^{15} \mathrm{NH}_{4}{ }^{+}$was probably retained relatively well in microbial cells and/or bound to the sediment and was therefore still available for incorporation in the light the following morning.

Acknowledgements. We thank P. van Rijswijk for processing and analyzing the PLFA samples, M. Houtekamer for his help with the GC-C-IRMS analyses and 2 anonymous reviewers for their constructive feedback. This work was supported by the Netherlands Organization for Scientific Research. This is Publication no. 4034 of the Netherlands Institute of Ecology (NIOO-KNAW).

\section{LITERATURE CITED}

Algeus S (1948) The deanimation of glycocoll by green algae. Physiol Plant 1:382-386

Andersson MGI, van Rijswijk P, Middelburg JJ (2006) Uptake of dissolved inorganic nitrogen, urea and amino acids in the Scheldt estuary: a comparison of organic carbon and nitrogen uptake. Aquat Microb Ecol 44:303-315

Antia NJ, Harrison PJ, Oliveira L (1991) The role of dissolved organic nitrogen in phytoplankton nutrition, cell biology and ecology. Phycologia 30:1-89

Barranguet C, Herman PMJ, Sinke JJ (1997) Microphytobenthos biomass and community composition studied by pigment biomarkers: importance and fate in the carbon cycle of a tidal flat. J Sea Res 38:59-70

Bronk DA (2002) Dynamics of DON. In: Hansell DA, Carlson CA (eds) Biogeochemistry of marine dissolved organic matter. Academic Press, San Diego, CA, p 153-247
Christensen D, Blackburn TH (1980) Turnover of tracer $\left({ }^{14} \mathrm{C}\right.$, ${ }^{3} \mathrm{H}$ labelled) alanine in inshore marine sediments. Mar Biol 58:97-103

Cowie GL, Hedges JI (1992) Sources and reactivities of amino acids in a coastal marine environment. Limnol Oceanogr 37:703-724

Dijkman NA, Kromkamp JC (2006) Phospholipid-derived fatty acids as chemotaxonomic markers for phytoplankton: application for inferring phytoplankton composition. Mar Ecol Prog Ser 324:113-125

Fan C, Glibert PM (2005) Effects of light on nitrogen and carbon uptake during a Prorocentrum minimum bloom. Harmful Algae 4:629-641

Fitznar HP, Lobbes JM, Kattner G (1999) Determination of enantiomeric amino acids with high-performance liquid chromatography and pre-column derivatisation with ophthaldialdehyde and N-isobutyrylcysteine in seawater and fossil samples (mollusks). J Chromatogr A 832: $123-132$

Jørgensen NOG (2006) Uptake of urea by estuarine bacteria. Aquat Microb Ecol 42:227-242

Kaiser K, Benner R (2005) Hydrolysis-induced racemization of amino acids. Limnol Oceanogr Methods 3:318-325

Kirchman DL, K'nees E, Hodson R (1985) Leucine incorporation and its potential as a measure of protein synthesis by bacteria in natural aquatic systems. Appl Environ Microbiol 49:599-607

Linares F, Sundbäck K (2006) Uptake of dissolved free amino acids (DFAA) by microphytobenthic communities. Aquat Microb Ecol 42:175-186

Lipschultz F (1995) Nitrogen-specific uptake rates of marine phytoplankton isolated from natural populations of particles by flow cytometry. Mar Ecol Prog Ser 123:245-258

Lund BA, Blackburn TH (1989) Urea turnover in a coastal marine sediment measured by a ${ }^{14} \mathrm{C}$-urea short term incubation. J Microbiol Methods 9:297-308

Middelburg JJ, Nieuwenhuize J (2000) Nitrogen uptake by heterotrophic bacteria and phytoplankton in the nitraterich Thames estuary. Mar Ecol Prog Ser 203:13-21

Middelburg JJ, Barranguet C, Boschker HTS, Herman PMJ, Moens T, Heip CHR (2000) The fate of intertidal microphytobenthos carbon: an in situ ${ }^{13} \mathrm{C}$-labeling study. Limnol Oceanogr 45:1224-1234

Mobley HLT, Hausinger RP (1989) Microbial ureases: significance, regulation and molecular characterization. Microbiol Rev 53:85-108

Mulholland MR, Glibert PM, Berg GM, Van Heukelem L, Pantoja S, Lee C (1998) Extracellular amino acid oxidation by microplankton: a cross-ecosystem comparison. Aquat Microb Ecol 15:141-152

Mulholland MR, Gobler CJ, Lee C (2002) Peptide hydrolysis, amino acid oxidation and nitrogen uptake in communities seasonally dominated by Aureococcus anophagefferens. Limnol Oceanogr 47:1094-1108

Mulholland MR, Lee C, Glibert PM (2003) Extracellular enzyme activity and uptake of carbon and nitrogen along an estuarine salinity and nutrient gradient. Mar Ecol Prog Ser 258:3-17

Mulholland MR, Boneillo G, Minor EC (2004) A comparison of $\mathrm{N}$ and $\mathrm{C}$ uptake during brown tide (Aureococcus anophagefferens) blooms from two coastal bays on the east coast of the USA. Harmful Algae 3:361-376

Palenik B, Morel FMM (1990) Amino acid utilization by marine phytoplankton: a novel mechanism. Limnol Oceanogr 35:260-269

Pantoja S, Lee C (1994) Cell-surface oxidation of amino acids in seawater. Limnol Oceanogr 39:1718-1726 
Price NM, Harrison PJ (1988) Uptake of urea C and urea N by the coastal marine diatom Thalassiosira pseudonana. Limnol Oceanogr 33:528-537

Schell DM (1974) Uptake and regeneration of free amino acids in marine waters of Southeast Alaska. Limnol Oceanogr 19:260-270

Simon M, Azam F (1989) Protein content and protein synthesis rates of planktonic marine bacteria. Mar Ecol Prog Ser 51:201-213

Soetaert K, Middelburg JJ, Heip C, Meire P, van Damme S and Maris $T$ (2006) Long-term change in dissolved inorganic nutrients in the heterotrophic Scheldt estuary (Belgium, The Netherlands). Limnol Oceanogr 51: 409-423

Stephens GC, North BB (1971) Extrusion of carbon accompanying uptake of amino acids by marine phytoplankters. Limnol Oceanogr 16:752-757

Tamminen T, Irmisch A (1996) Urea uptake kinetics of a midsummer planktonic community on the SW coast of Finland. Mar Ecol Prog Ser 130:201-211

Tobias C, Giblin A, McClelland J, Tucker J, Peterson B (2003) Sediment DIN fluxes and preferential recycling of benthic microalgal nitrogen in a shallow macrotidal estuary. Mar Ecol Prog Ser 257:25-36

van Oevelen D, Soetaert K, Middelburg JJ, Herman PMJ, Moodley L, Hamels I, Moens T, Heip CHR (2006) Carbon

Editorial responsibility: Bess Ward,

Princeton, New Jersey, USA flows through a benthic food web: integrating biomass, isotope and tracer data. J Mar Res 64:453-482

Veuger B, Middelburg JJ, Boschker HTS, Nieuwenhuize J, van Rijswijk P, Rochelle-Newall EJ, Navarro N (2004) Microbial uptake of dissolved organic and inorganic nitrogen in Randers Fjord. Estuar Coast Shelf Sci 61:507-515

Veuger B, Middelburg JJ, Boschker HTS, Houtekamer M (2005) Analysis of ${ }^{15} \mathrm{~N}$ incorporation into D-alanine: a new method for tracing nitrogen uptake by bacteria. Limnol Oceanogr Methods 3:230-240

Veuger B, van Oevelen D, Boschker HTS, Middelburg JJ (2006) Fate of peptidoglycan in an intertidal sediment: an in situ ${ }^{13} \mathrm{C}$-labeling study. Limnol Oceanogr 51:1572-1580

Veuger B, Eyre BD, Maher D, Middelburg JJ (2007) Nitrogen incorporation and retention by bacteria, algae, and fauna in a subtropical, intertidal sediment: an in situ ${ }^{15} \mathrm{~N}$-labeling study. Limnol Oceanogr 52(5):(in press)

Wheeler PA, Kirchman DL (1986) Utilization of inorganic and organic nitrogen by bacteria in marine systems. Limnol Oceanogr 31:998-1009

Zehr JP, Ward BB (2002) Nitrogen cycling in the ocean: new perspectives on processes and paradigms. Appl and Environ Microbiol 68:1015-1024

Zehr JP, Axler RP, Goldman CR (1985) Heterotrophic mineralization of amino acid nitrogen in subalpine Castle Lake, California. Mar Chem 16:343-350

Submitted: April 24, 2006; Accepted: April 9, 2007

Proofs received from author(s): May 22, 2007 